EESTI NSV TEADUSTE AKADEEMIA TOIMETISED. 21. KOIDE

KEEMIA * GEOLOOGIA. 1972, NR. 1

ИЗВЕСТИЯ АКАДЕМИИ НАУК ЭСТОНСКОН ССР, ТОМ 21

ХИМия * ГЕОЛОГИя. 1972, № 1

\title{
МИКРОПАЛЕОНТОЛОГИЧЕСКАЯ ХАРАКТЕРИСТИКА ЮЛЬГАЗЕСКОЙ ПАЧКИ ТРЕМАДОКА ЭСТОНИИ
}

\begin{abstract}
7. JANKAUSKAS, L. PASKEVICENE. EESTI TREMADOKI OLGASE KIHISTIKU MIKROPALEONTO LOOGILINE ISELOOMUSTUS
\end{abstract}

T. JANKAUSKAS, L. PASKEVICIENE. MICROPALEONTOLOGICAL CHARACTERISTICS OF THE: TKEMADOCIAN OLGASE MEMBER OF ESTONIA

Юльгазеская пачка является самым древним подразделением пакерортского горизонта Эстонии (Ӧрik, 1929; Мююрисепп, 1960; Лоог, Кивимяги, 1968). Она резко несогласно залегает на песчаниках тискреской свиты нижнего кембрия и также несогласно перекрывается более молодыми отложениями. Пачка сложена белыми песчанистыми алевролитами, содержащими прослои частично побуревших серовато-зеленых глин. Общая мощность пачки от 6 до 25 м. Территориальное распространение ее ограничивается небольшим районом в северной части Эстонии (Лоог, Кивимяги, 1968).

Пакерортский горизонт в целом разными исследователями в разное время относился то к верхнему кембрию, то к ордовику. К настоящему времени установилось мнение о его ордовикском возрасте. Тем не менее, в определенной степени дискуссионным остался вопрос о возрасте самой нижней части пакерорта - юльгазеской пачки. В ее породах встречаются остатки оболид и Acrotreta, но еще нет характерной для пакерортского горизонта Dictyonema. Уже А. Эпик (Öpik, 1928, 1929) допускал возможность верхнекембрийского возраста юльгазеской пачки (его зона Acrotreta), считая доказанным ордовикский возраст лишь перекрываю щих ее отложений. Е. Балашова (1963) предполагаемые аналоги юльга зеской пачки в Пестовской скважине Новгородской области отнесла к верхнему кембрию.

Авторами настоящего сообщения изучены акрнтархи из глинистых прослоев стратотипического разреза юльгазеской пачки в районе рудника Юльгазе. Общая мощность пачки в этом разрезе 6,7 м. Пробы на акритархи были отобраны из пяти прослоев глин, находящихся на разных стратиграфических уровнях (рисунок). Во всех пробах обнаружена масса акритарх (сотни и тысячн экземпляров в каждом препарате). Все они относятся к видам, известным только из тремадокских отложений Әстонии и других территорий. Типичные для кембрия формы (судя по имеющимся данным) здесь не обнаружены.

Характерные для тремадока Восточно-Европейской платформы акритархи (Наумова, 1950) установлены уже в самой нижней пробе № 89/71 (0,7 м выше подошвы пачки) и представлены видами: Baltisphaeridium spectatissimum (Naum.), B. aciferum (Naum.), B. crassum (Naum.), B. antiquum (Naum.), B. serratum (Naum.), B. incompletum (Naum.), 
B. cf. perspicuum (Naum.), Latoporata? membranacea (Naum.), Zonosphaeridium papillosum (Naum.). Совместно с ними встречены следующие известные в тремадоке Сахары (Deunff, 1961) виды: Vulkanisphaera africana Dff., Cymatiogalea margaritata Dif., C. curillieri Dff., C. gassiense Dff., C. multiclaustra Dff. Здесь же найде ны неизвестные ниже тремадока крупные формы Leiofusa, Metaleiofusa, Veryhachium, мелкие Diacromorphitae и ряд новых видов.

Стратотипический разрез юльгазеской пачки у рудника Юльгазе.

1 - задерновано; 2 - песчаники маардуской пачкн; 3 - прослои темных аргиллитов (диктионемовых сланцев); 4 песчанистые алевролиты юльгазеской пачки; 5 - прослои глинистых пород; 6 - песчаники нижнекембрийской тискреской свиты; 7 -- места отбора проб и их номер.

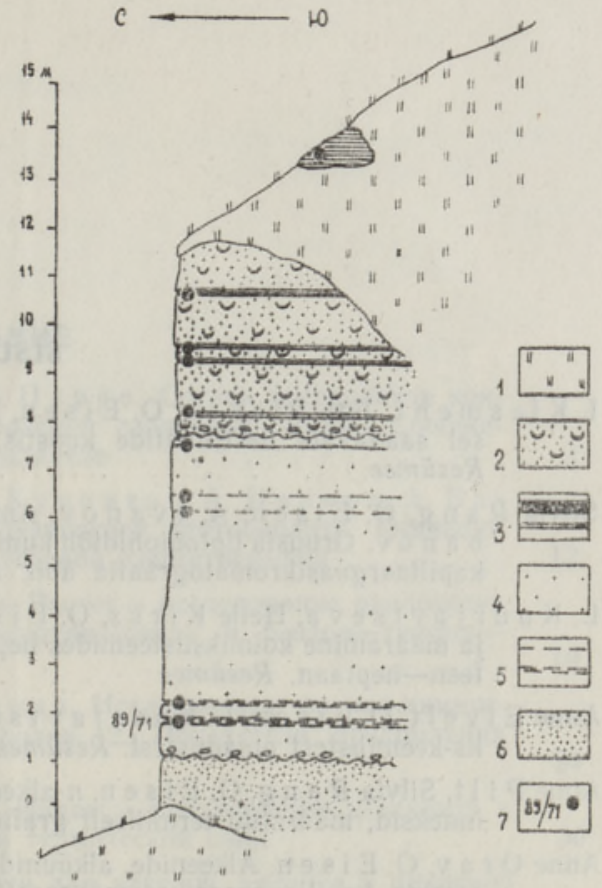

В таком составе комплекс акритарх прослеживается по всему разрезу юльгазеской пачки, во всех пяти пробах (см. рисунок). Он близок к комплексу акритарх из вышележащих отложений пакерортского горизонта как в этом разрезе, так и в других районах (Уманова, Вандерфлит, 1971; Тимофеев, 1959).

Таким образом, можно заключить, что юльгазеская пачка, судя по акритархам, во-первых, тесно связана с остальной частью пакерортского горизонта и, во-вторых, несомненно относится к тремадоку.

\section{ЛИТЕРАТУ Р А}

Бал а шов а Е. А. 1963. Первая находка верхнекембрийских трилобнтов на Русской платформе. Вестн. ЛГУ, Сер. геол. и географ., № 12.

Л о о А., Кив и я г и Э. 1968. Литостратиграфия пакерортского горизонта в Эстонии. Изв. АН ЭССР, Хим. Геол., 17, № 4.

М ю юр и се п п К. 1960. Лнтостратиграфия пакерортского горизонта в Эстонской ССР по данным обнаженпй. Тр. Ин-та геол. АН ЭССР, 5.

Н а у м о в а С. Н. 1950. Споры нижнего силура. Тр. конфер. по споро-пыльцевому анализу, 1948 г., М.

Т и м о фе е в Б. В. 1959. Древнейшая флора Прибалтикн. Л.

у мн ов а Н. И., Ванде рфлит Е. К. 1971. Комглексы акригарх кембрийскнх и нижнеордовикских отложений занада и северо-запада Русской платформы. В кн.: Палеонтологические исследования в Белоруссии и других районах СССР Минск.

Deunff J. 1961. Un microplankton à hystrichosphaeres dans le Tremadoc du Sahara, Revue de Micropaléontologie, $4, \mathrm{n}^{\circ} \mathrm{I}$.

O pik A. A. 1928. O novejšich vyzkumech v estnskem kambru a ordoviku. Vedy prirodni, roc. IX. Praga.

Opik A. A. 1929. Der estländische Obolenphosphorit. Tartu Olik. Geol. Toimet,, nr. 18.

\section{Институт геологии (Вильнюс)}

